\title{
An Ana-Ano-MBR system for nutrient removal from brewery wastewater at various nitrate recirculation ratios
}

\author{
Van Nu Thai Thien, Dang Viet Hung, Nguyen Thi Thanh Hoa
}

\begin{abstract}
Anaerobic and anoxic variations were combined with membrane bioreactor to form an Anaerobic/Anoxic configuration in MBR-based (Ana-Ano-MBR) system for improving the system performance in terms of organic degradation and nutrient removal from brewery wastewater. The model of Ana-Ano-MBR system made from polyacrylic with the capacity of 42 liters was operated with organic loading rate of 0.75 $\mathrm{kgCOD} / \mathrm{m}^{3}$.day. The results showed that for the nitrate recycling ratios of $100,200,300 \%$, average $\mathrm{NH}_{4}{ }^{+}-\mathrm{N}$ and TN removal efficiencies of the model were 95.1 and 76.6, 98.5 and 89.6, 98.9 and $90.2 \%$, respectively, and the output values of $\mathrm{NH}_{4}{ }^{+}-\mathrm{N}$ and TN were within the limits of Vietnam National Standards (QCVN 40:2011/BTNMT, column A). Treatment efficiencies of COD and TP were over $90 \%$ and below $60 \%$, respectively, during the whole experiment period. Low phosphorus removal efficiency was the drawback of Ana-Ano-MBR system due to the lack of appropriate system configuration and operational conditions for PAOs' growth and activity.
\end{abstract}

Index Terms-Ana-Ano-MBR system, Brewery wastewater

\section{INTRODUCTION}

$\mathrm{B}$ eer production in Vietnam has grown considerably since 1996. By Vietnam Beer Alcohol Beverage Association (VBA), beer

Received: July 23 ${ }^{\text {th }}, 2018$; Accepted: Oct 11 $11^{\text {th }}$ 2018; Published: Dec 31 $1^{\text {st }}, 2018$

Van $\mathrm{Nu}$ Thai Thien, Institute for Environment and Resources - VNU-HCM (Email: vannuthaithien@gmail.com).

Dang Viet Hung, Ho Chi Minh City University of Technology - VNU-HCM (Email: dvhung70@gmail.com).

Nguyen Thi Thanh Hoa, Ho Chi Minh City University of Natural Resources and Environment (Email: ntthoa@hcmunre.edu.vn). production in Vietnam reached 3.4 billion liters in 2015, a 4.7 percent year on year increase. After beer brewing process, large amounts of wastewater with high concentrations of organic compounds and nutrients ( $\mathrm{N}$ and $\mathrm{P}$ ) must be treated to meet the discharge standards.

Anaerobic/Anoxic/Oxic $\left(\mathrm{A}_{2} \mathrm{O}\right)$ system is a wellknown biological nutrient removal system with its own inherent advantages such as short hydraulic retention time, less sludge bulking, low processing costs and excess sludge with high phosphorus concentration. The system consists of three anaerobic, anoxic, oxic reactors and one settling tank linked in-series with nitrate recycling flow from the oxic reactor to the anoxic reactor and sludge recycling flow from the settling tank to the anaerobic reactor. In this system, nitrification by nitrifiers occurs in the oxic reactor; denitrification by denitrifiers in the anoxic reactor; absorption of $\beta$-polyhydroxybutyrate (PHB) for phosphate release by Phosphorus Accumulating Organisms (PAOs) in the anaerobic reactor and then oxidation of PHB for phosphorus accumulation in the oxic reactor; and discharge of excess sludge in the settling tank [1, 2]. It is apparent that the higher the nitrate recirculation ratio is, the more the denitrification rate reaches. Nitrogen removal efficiency can be further improved if a higher nitrate recycling ratio is adopted. However, high nitrate recirculation ratios ( $\geq 400 \%$ ) should be avoided from an economical point of view [3, 4].

Membrane Bioreactor (MBR) is an attractive process that has been increasingly used for advanced wastewater treatment. With membrane filtration replacing secondary clarification, MBR has several advantages over conventional 
activated sludge process, including small reactor size; good effluent quality and low sludge production. By effective biomass-effluent separation with membrane modules, a MBR can achieve complete sludge retention for attaining high-sludge concentration and long solids retention time (SRT) [5-8]. More recently, it was reported that $\mathrm{A}_{2} \mathrm{O}$ system performance in terms of organic degradation and nutrient removal could be improved by incorporating membrane separation into this system [9, 10]. A novel wastewater treatment combining system, so-called Anaerobic/Anoxic/MBR (Ana-Ano-MBR) system, has been put forward. In this system, the MBR is used to replace the oxic reactor and the settling tank will become unnecessary. Although there were numerous reports on carrying out nutrient removal in Ana-Ano-MBR system, little information was currently available in the literature about operating conditions affecting on removal efficiencies.

In this study, an Ana-Ano-MBR system was used to evaluate the effects of nitrate recirculation ratio on the combined system's simultaneous nitrogen and phosphorus removal performance via continuous flow by treating real brewery wastewater. The role of membrane separation in the combined system and its contribution to chemical oxygen demand (COD), nitrogen and phosphorus removal were also investigated.

\section{MATERIALS AND METHODS}

\subsection{Raw wastewater, Seed sludge}

Real brewery wastewater was collected at the outlet of the UASB reactor of Wastewater Treatment Plant at Nguyen Chi Thanh - Saigon Beer Manufactoring Factory, Ho Chi Minh City, Vietnam. Compositions and properties of influent wastewater of the model were represented as $\mathrm{pH}$ : 6.2 - 7.6; COD: $498 \pm 45 \mathrm{mg} / \mathrm{L}$; suspended solid (SS): $118 \pm 74 \mathrm{mg} / \mathrm{L} ; \mathrm{NH}_{4}{ }^{+}-\mathrm{N}: 46.5 \pm 8.9 \mathrm{mg} / \mathrm{L}$; total nitrogen $(\mathrm{TN})$ : $48.6 \pm 10.1 \mathrm{mg} / \mathrm{L}$; total phosphorus (TP): $9.9 \pm 3.5 \mathrm{mg} / \mathrm{L}$. Seed sludge for the Ana-Ano-MBR system was taken from one of the two SBRs of this wastewater treatment plant. Seed sludge was light brown, well-settled with SVI $<96$ and MLVSS/MLSS ratio of 0.73 .

\subsection{Experimental system}

A polyacrylic model of Ana-Ano-MBR system was developed and operated for the experimental study. The schematic representation of the experimental system is shown in Figure 1. The model had an approximate dimension of $700 \mathrm{~mm}$ (L) $\times 100 \mathrm{~mm}(\mathrm{~W}) \times 700 \mathrm{~mm}(\mathrm{H})$ with the corresponding working volume of 42.0 liters which was divided by baffles to create three reactors (anaerobic reactor, anoxic reactor and MBR) in the ratio of 9:9:24 [11]. In the MBR, a polyethylene hollow-fiber membrane module (0.4 $\mu \mathrm{m}$ pore size, $0.32 \mathrm{~m}^{2}$ effective area, Mitsubishi Rayon Co., Ltd, Japan) was immersed. Effluent was withdrawn through the membrane module by a suction pump which was set off for 2 min every $10 \mathrm{~min}$ for membrane relaxation. To mitigate membrane fouling, backflushing was carried out every 24 hours for $15 \mathrm{~min}$. Aeration was provided through fine air diffusers from the bottom in the MBR while sludge in the anaerobic and anoxic reactors were suspended by paddle mixers at $50 \mathrm{rpm}$. DO concentrations of the MBR were determined by DO meter and controlled from 2 to $4 \mathrm{mg} / \mathrm{L}$.

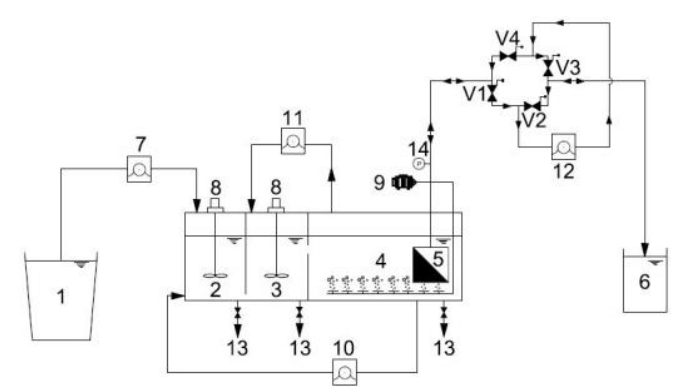

Figure 1. Schematic representation of the experimental system. Note that 1/Influent tank: 120 liters (PE, Vietnam); 2 -4/Three reactors of the model: 42.0 liters (Polyacrylic, Vietnam); 5/Membrane module: (Mitsubishi Rayon Co., Ltd, Japan); 6/Effluent tank: 60 liters (PE, Vietnam); 7/Influent pump: 11 liters/hour (Blue \& White, United State); 8/Paddle mixers: 50 rpm (IWAKI, Japan); 9/Blower: 38 liters/min (RESUN, Ap 001, China); 10/Sludge recirculation pump: 11 liters/hour (Blue \& White, United State); 11/Nitrate recirculation pump: 30 liters/hour (Blue \& White, United State); 12/Effluent pump: 11 liters/hour (Blue \& White, United State); 13/Sludge valves: $\varnothing 13$ (Copper, Vietnam). 


\subsection{Experimental set-up}

The wastewater treatment experiment was conducted in four phases. In the short first phase, seed sludge was given to $50 \%$ volume of the model with MLSS concentration about 5000 $\mathrm{mg} / \mathrm{L}$. Raw wastewater with average COD concentration of $500 \mathrm{mg} / \mathrm{L}$ diluted with tap water was pumped into the model. Organic loading rate was increased little by little from 0.1 to 0.3 $\mathrm{kgCOD} / \mathrm{m}^{3}$.day correspond to hydraulic retention time decreased from 60 to 20 hours and wastewater flow rate increased from 16.8 to 50.4 liters/day. Nitrate recirculation ratio from the MBR to the anoxic reactor was $100 \%$ and sludge recirculation ratio from the MBR to the anaerobic reactor was $100 \%$. The first phase ended when COD removal efficiency remained stable at above $80 \%$. There was no sludge discharged except sampling to provide large amounts of biomass.

In the next three phases denoted as 2, 3 and 4, respectively, nitrate recycling ratios were increased from 100 to $300 \%$ while sludge recycling ratios were maintained at $100 \%$. A raw wastewater was pumped continuously with wastewater flow rate of 63 liters/day corresponding to hydraulic retention time of 18 hours and organic, nitrogen, phosphorus loading rates of $0.75 \mathrm{kgCOD} / \mathrm{m}^{3}$.day, $0.092 \mathrm{kgTN} / \mathrm{m}^{3}$.day, $0.014 \mathrm{kgTP} / \mathrm{m}^{3}$.day, respectively. Excess sludge was manually discharged to keep SRT of 21 days.

Trans-membrane pressure (TMP) was used as an indicator of membrane fouling and monitored continously by a data logging manometer. When TMP reached $40 \mathrm{kPa}$, membrane washing was performed physically and chemically following the guidelines of the manufacturer. In the phases $1,2,3$ and 4, the membrane module was physically washed on a daily basis for $15 \mathrm{~min}$. During the entire period of experiment, the TMP was maintained below $40 \mathrm{kPa}$. Therefore, the membrane module was not cleaned chemically.

\subsection{Analytical methods}

The samples were collected at the input and output positions of the experimental system. They were also collected in the three reactors of the model. The parameters of wastewater such as $\mathrm{pH}$,
COD, SS, TKN, $\mathrm{NH}_{4}{ }^{+}-\mathrm{N}, \mathrm{NO}_{2}^{-}-\mathrm{N}, \mathrm{NO}_{3}^{-}-\mathrm{N}, \mathrm{TN}$, TP were analyzed according to Vietnam National Standards (QCVN) together with Standard Methods for the Examination of Water and Wastewater (APHA, AWWA, and WEF) [12] at Research Institute for Aquaculture No.2 in Ho Chi Minh City. For each loading rate, the model was operated for 45 days to achieve a steady-state condition and the samples were collected over a 3-day period during these days. The results below were based on average value and standard deviation by using Microsoft Office Excel software.

\section{RESULTS AND DISCUSSION}

\subsection{Organic removal efficiency}

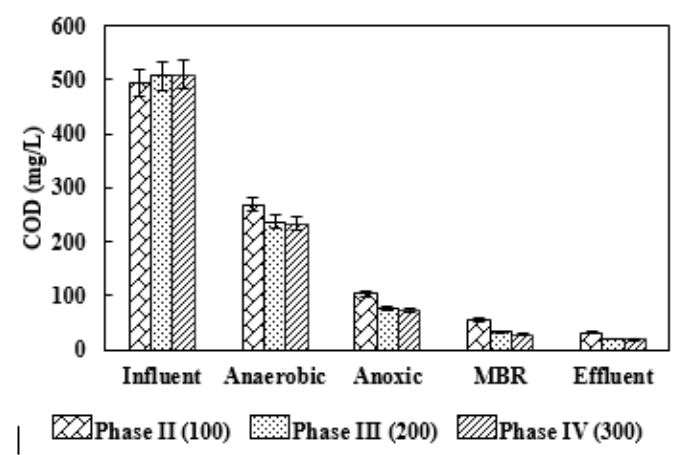

Figure 2. Change of COD concentration at various nitrate recycling ratios.

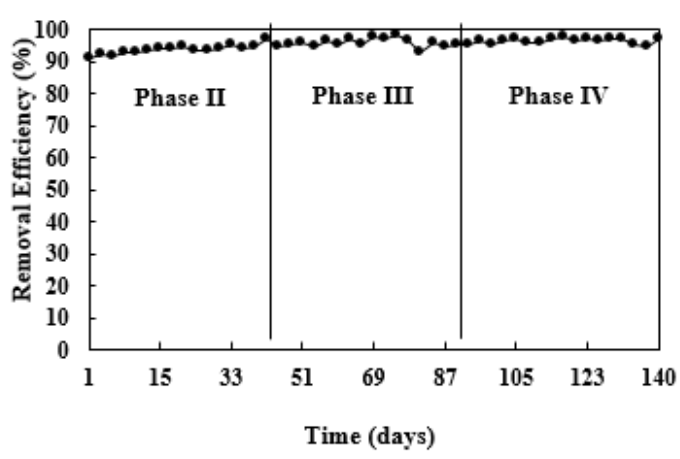

Figure 3. COD removal efficiencies at various nitrate recycling ratios.

Figure 2 shows COD concentrations at different positions of the experimental system and Figure 3 indicates variation of COD removal efficiencies during the whole period of operation. It could be seen that COD concentration decreased significantly in the anaerobic and anoxic reactors. 
The decline could be attributed mainly by the dilution of the return flow from the MBR to the anaerobic and anoxic reactors. The major part of influent COD was consumed in the MBR and anoxic reactor. The overall $\mathrm{COD}$ removal is mainly due to biological degradation in the AnaAno-MBR system rather than membrane separation in the MBR, while membrane filtration is beneficial to keep a higher COD removal efficiency $[13,14]$. In the experimental system, SRT of 21 days was effectively controlled to achieve a high removal rate of organic matter, whereas, due to this long SRT, nitrifying bacteria could be enriched. When the nitrate recycling ratios varied from 100 to $300 \%$, the effluent COD concentrations decreased from 31 to $18 \mathrm{mg} / \mathrm{L}$, which were much lower than the limit of QCVN 40:2011/BTNMT, column A and the corresponding removal efficiencies of COD were 93.7, 96.3 and $96.5 \%$, respectively. A higher nitrate recirculation ratio will result in a higher $\mathrm{NO}_{3}{ }^{-} \mathrm{N}$ load in the anoxic reactor. Therefore, along with the increasing of nitrate recycling ratio, a slightly high percentage of COD removal in the anoxic reactor was due to denitrification COD uptake and aerobic oxidization as a result of DO recirculation [3, 15]. Previous studies also found that the full retention of biomass concentration made the membrane-based system less sensitive to the changes in operational conditions $[13,16]$.

\subsection{Nitrogen removal efficiency}

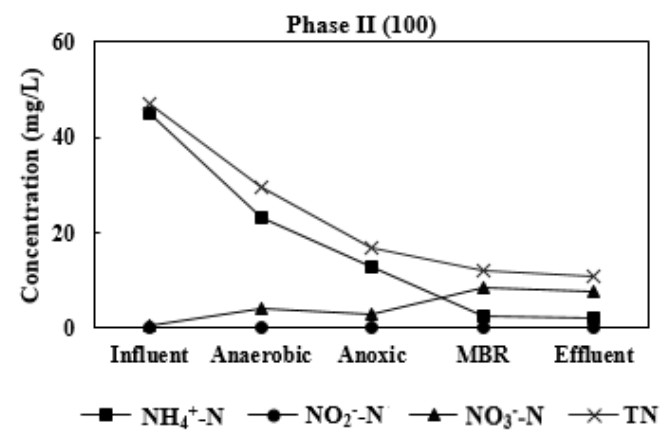

Figure 4. Conversion of nitrogen concentration for a nitrate recycling ratio of $100 \%$.

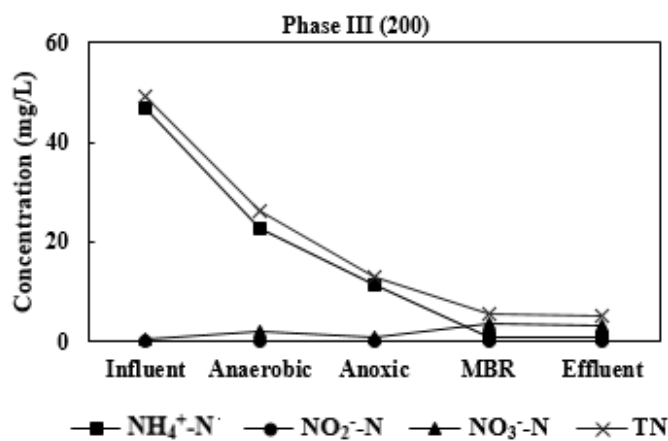

Figure 5. Conversion of nitrogen concentration for a nitrate recycling ratio of $200 \%$.

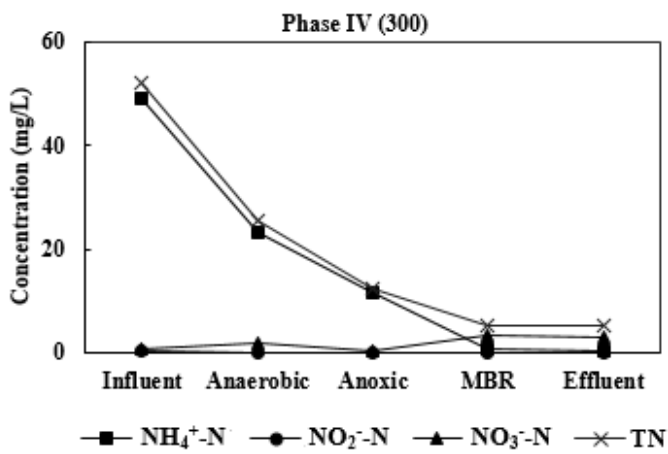

Figure 6. Conversion of nitrogen concentration for a nitrate recycling ratio of $300 \%$.

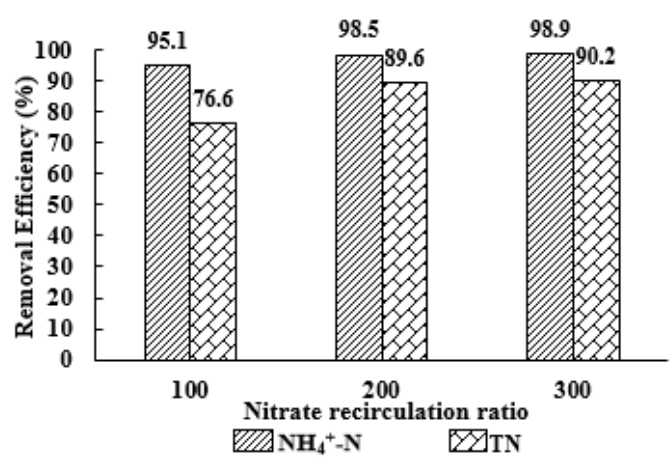

Figure 7. Nitrogen removal efficiencies at various nitrate recycling ratios.

The effects of three various nitrate recycling ratios $(100,200$ and $300 \%)$ on nitrogen removal of the experimental system were revealed in Figures 4, 5, 6 and 7. $\mathrm{NH}_{4}{ }^{+}-\mathrm{N}$ and $\mathrm{TN}$ concentrations decreased significantly in the anaerobic and anoxic reactors due to the dilution of sludge circulating flow (ratio of 100\%) and nitrate circulating flow (ratios ranged from 100 to $300 \%)$. TN at the anoxic reactor was mostly $\mathrm{NH}_{4}{ }^{+}-\mathrm{N}$ and $\mathrm{TN}$ at the MBR was mostly $\mathrm{NO}_{3}{ }^{-}-\mathrm{N}$. 
Nitrification hardly occured in the MBR and a large amount of $\mathrm{NH}_{4}{ }^{+}-\mathrm{N}$ was completely transformed. As mentioned above, long SRT applied in the MBR prevent nitrifying bacteria from being washed out from this bioreactor, hence improving the nitrification capability of the activated sludge [5]. Very low $\mathrm{NO}_{3}-\mathrm{N}$ concentration in the anoxic reactor indicated that denitrification happened as much as possible in the anoxic reactor [3]. The MBR and anoxic reactor played their roles very well to remove nitrogen. Moreover, a small amount of $\mathrm{NH}_{4}{ }^{+}-\mathrm{N}$ was metabolized for the growth of microorganisms in the model. For the nitrate recycling ratios of $100,200,300 \%$, average $\mathrm{NH}_{4}{ }^{+}$$\mathrm{N}$ and TN removal efficiencies of the model were 95.1 and 76.6, 98.5 and 89.6, 98.9 and 90.2\%, respectively, and the output values of $\mathrm{NH}_{4}{ }^{+}-\mathrm{N}$ and TN were within the limits of QCVN 40:2011/BTNMT, column A. It was fully reasonable with the change of COD stated above. Together with organic removal, nitrogen removal exhibited an incremental trend with the increase of nitrate recirculation ratio. The results also showed that a proper denitrification could be obtained in the experimental system with a nitrate recycling ratio of $200 \%$ based on the economic cost of nitrate recycling directly related to its flow rate.

\subsection{Phosphorus removal efficiency}

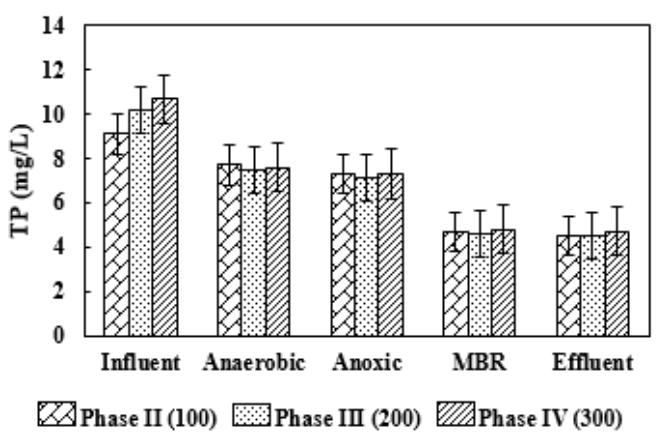

Figure 8. Conversion of TP concentration at various nitrate recycling ratios.

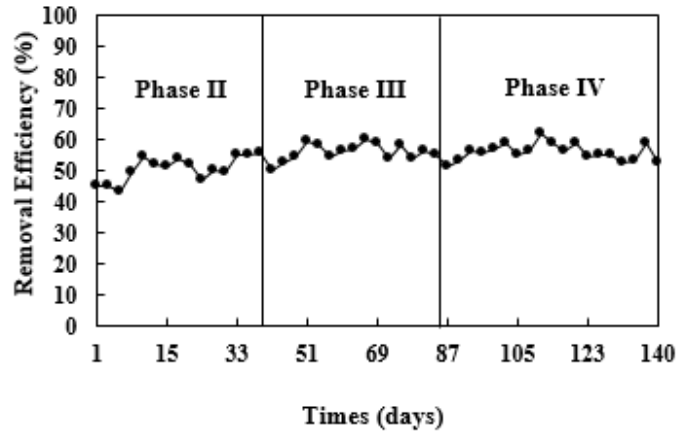

Figure 9. TP removal efficiencies at various nitrate recycling ratios.

Figure 8 depicts TP concentrations at different positions in the experimental system for the three phases and low TP removal efficiency is consequently observed in Figure 9. TP concentration gradually decreased in the following steps of the treatment process. TP removal efficiency was no more than $60 \%$ during the running period of each loading rate, which also suggested that TP removal via assimilation was below $60 \%$. TP concentration in the anaerobic reactor was not significantly higher than that in the MBR. This implies that the PAOs community was not well developed in the AnaAno-MBR system. Conditions that favor PAOs growth and anaerobic phosphorus release could not be provided. By the presence of a significant amount of dissolved oxygen and nitrate in the anaerobic reactor due to the return flow from the MBR, the volatile fatty acids (VFAs) were depleted before it could be taken up by the PAOs and treatment performance was hindered due to less growth of PAOs [4]. A further explanation of this can be due to SRT of 21 days. Long SRT can reduce the effectiveness of phosphorus removal. The Ana-Ano-MBR system is a single sludge system so there has been limitation to satisfy an proper SRT for both nitrifiers and PAOs in the MBR of the model [17]. For the phases of 2, 3, 4; average TP removal efficiencies of the model were $50.5,55.9,56.1 \%$, respectively. TP removal efficiency in this system had a slight increase when nitrate recycling ratio was increased because effect of sludge circulating flow containing nitrate was lower. For all three loading rates, the output values of TP were within the limit of QCVN 40:2011/BTNMT, column B. 


\subsection{Membrane fouling}

Membrane fouling in MBR were inevitable. The TMP in the MBR of the model was monitored continuously to evaluate the membrane fouling during the entire running period. The TMP was in the range of $10-26 \mathrm{kPa}$ with the flux of $8.1 \mathrm{~L} / \mathrm{m}^{2} . h(\mathrm{LMH})$. The membrane fouling rate in the MBR correlates well with the MLSS concentration [18]. Figures 10 and 11 show the variations of TMP and MLSS concentration during 140 days of operation. The MLSS concentration initially increased from around $5600 \mathrm{mg} / \mathrm{L}$ to nearly $6100 \mathrm{mg} / \mathrm{L}$ on day 38 and was maintained for the remaining days of running. The TMP increased almost linearly and reached about $26 \mathrm{kPa}$ on day 136. As mentioned above, the membrane fouling could be alleviated to a certain degree by the intermittent operation of the membrane ( 2 min rest in every 10 min operation), air bubbling and backflushing.

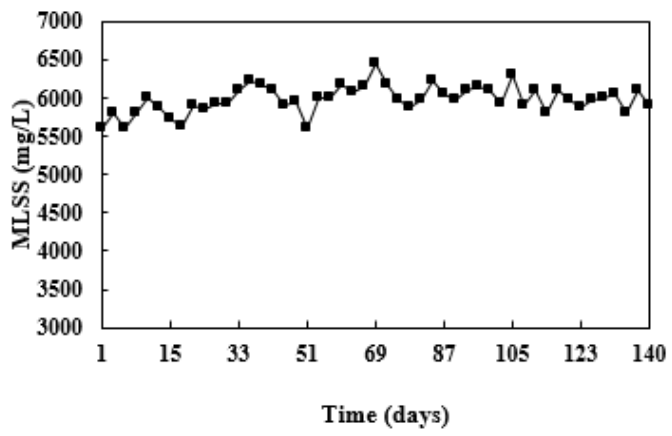

Figure 10. Variation of MLSS concentration during the operational period.

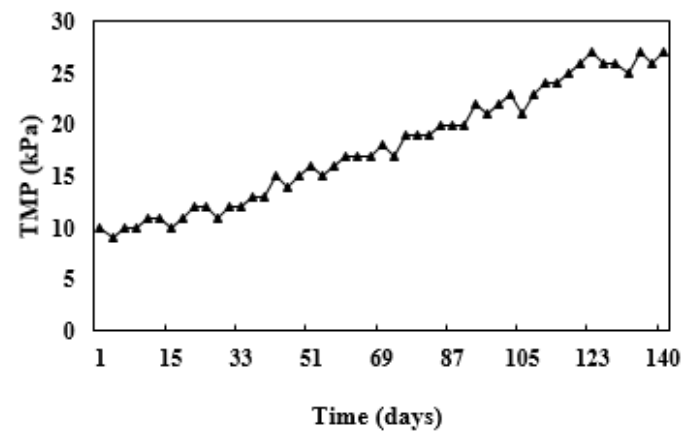

Figure 11. Variation of TMP during the operational period.

\section{CONCLUSIONS}

In this study, the model of Ana-Ano-MBR system was operated with various nitrate recycling ratios. $\mathrm{COD}$ and $\mathrm{TP}$ removal efficiencies had a slight increase when nitrate recycling ratio was increased. Treatment efficiencies of COD and TP were over $90 \%$ and below $60 \%$, respectively, during the whole experiment period. $\mathrm{NH}_{4}{ }^{+}-\mathrm{N}$ and $\mathrm{TN}$ removal efficiencies exhibited an incremental trend with the increase of nitrate recirculation ratio. For nitrate recycling ratio of $300 \%$, treatment efficiencies of COD, $\mathrm{NH}_{4}{ }^{+}-\mathrm{N}, \mathrm{TN}$ and TP of the model were $96.5,98.9,90.2$ and $56.1 \%$, respectively. Phosphorus removal efficiency was relatively low due to the lack of appropriate system configuration and operational conditions for PAOs' growth and activity. In this system, phosphorus removal would be probably influenced when taking nitrogen removal into the first consideration.

\section{REFERENCES}

[1] Yong Ma, Yongzhen Peng, Xiaolian Wang, "Improving nutrient removal of the AAO process by an influent bypass flow by denitrifying phosphorus removal", Journal of Desalination, vol. 246, no. 1-3, pp. 534-544, 2009.

[2] Shijian Ge, Yunpeng Zhu, Congcong Lu, Shuying Wang, Yongzhen Peng, "Full-scale demonstration of step feed concept for improving an anaerobic/anoxic/aerobic nutrient removal process", Journal of Bioresource Technology, vol. 120, pp. 305-313, 2012.

[3] Yongzhi Chen, Chengyao Peng, Jianhua Wang, Liu Ye, Liangchang Zhang, Yongzhen Peng, "Effects of nitrate recycling ratio on simultaneous biological nutrient removal in a novel anaerobic/anoxic/oxic (A2/O) biological aerated filter (BAF) system", Journal of Bioresource Technology, vol. 102, pp. 5722-5727, 2011.

[4] J.C. Leyva-Díaz, M.M. Munío, J. González-López, J.M. Poyatos, "Anaerobic/anoxic/oxic configuration in hybrid moving bed biofilm reactor-membrane bioreactor for nutrient removal from municipal wastewater", Journal of Ecological Engineering, vol. 91, pp. 449-458, 2016.

[5] Simon Judd, Claire Judd, "The MBR Book: principles and applications of membrane bioreactors in water and wastewater treatment", Elsevier, 2006.

[6] J. Arévalo, L.M. Ruiz, J.A. Parada-Albarracín, D.M. González-Pérez, J. Pérez B Moreno, M.A. Gómez, "Wastewater reuse after treatment by MBR. Microfiltration or ultrafiltration?", Journal of Desalination, vol. 299, pp. 22-27, 2012.

[7] Carlos M. Barreto, Hector A. Garcia, Christine M. Hooijmans, Aridai Herrera, Damir Brdjanovic, "Assessing the performance of an MBR operated at high biomass concentrations", Journal of International Biodeterioration \& Biodegradation, vol. 119, pp. 528537, 2017.

[8] Fangang Meng, Shaoqing Zhang, Yoontaek Oh, Zhongbo Zhou, Hang-Sik Shin, So-Ryong Chae, "Fouling in membrane bioreactors: An updated review", Journal of Water Research, vol. 114, pp. 151-180, 2017.

[9] Yisong $\mathrm{Hu}$, Xiaochang C. Wang, Yongmei Zhang, 
Yuyou Li, Hua Chen, Pengkang Jin, "Characteristics of an A2O-MBR system for reclaimed water production under constant flux at low TMP", Journal of Membrane Science, vol. 431, pp. 156-162, 2013.

[10] Hadi Falahti-Marvast, Ayoub Karimi-Jashni, "Performance of simultaneous organic and nutrient removal in a pilot scale anaerobic-anoxic-oxic membrane bioreactor system treating municipal wastewater with a high nutrient mass ratio", Journal of International Biodeterioration and Biodegradation, vol. 104, pp. $363-$ 370, 2015.

[11] Li-Mei Yuan, Chuan-Yi Zhang, Yan-Qiu Zhang, Yi Ding, Dan-Li Xi, "Biological nutrient removal using an alternating of anoxic and anaerobic membrane bioreactor (AAAM) process", Journal of Desalination, vol. 221, pp. 566-575, 2008.

[12] Standard Methods for the Examination of Water and Wastewater, 20th Edition, APHA, AWWA, and WEF, 1998.

[13] Fei-yun Sun, Xiao-mao Wang, Xiao-yan Li, "An innovative membrane bioreactor (MBR) system for simultaneous nitrogen and phosphorus removal", Journal of Process Biochemistry, vol. 48, pp. 1749-1756, 2013.

[14] Hanmin Zhang, Xiaolin Wang, Jingni Xiao, Fenglin Yang, Jie Zhang, "Enhanced biological nutrient removal using MUCT-MBR system", Journal of Bioresource Technology, vol. 100, pp. 1048-1054, 2009.
[15] Mehran Andalib, George Nakhla, Dipankar Sen, Jesse Zhu, "Evaluation of biological nutrient removal from wastewater by Twin Circulating Fluidized Bed Bioreactor (TCFBBR) using a predictive fluidization model and AQUIFAS APP", Journal of Bioresource Technology, vol. 102, no. 3, pp. 2400-2410, 2011.

[16] Kyung-Guen Song, Jinwoo Cho, Kang-Woo Cho, SangDon Kim, Kyu-Hong Ahn, "Characteristics of simultaneous nitrogen and phosphorus removal in a pilot-scale sequencing anoxic/anaerobic membrane bioreactor at various conditions", Journal of Desalination, vol. 250, pp. 801-804, 2010.

[17] Weitang Zhang, Yongzhen Peng, Nanqi Ren, Qingsong Liu, Yongzhi Chen, "Improvement of nutrient removal by optimizing the volume ratio of anoxic to aerobic zone in AAO-BAF system", Journal of Chemosphere, vol. 93, no. 11, pp. 2859-2863, 2013.

[18] Fangang Meng, So-Ryong Chae, Anja Drews, Matthias Kraume, Hang-Sik Shin, Fenglin Yang, "Recent advances in membrane bioreactors (MBRs): Membrane fouling and membrane material", Journal of Water Research, vol. 43, no. 6, pp. 1489-1512, 2009.

\title{
Nghiên cứu loại bỏ thành phần dinh dưỡng từ nước thải sản xuất bia bằng hệ thống Ana-Ano- MBR ở các tỷ lệ tuần hoàn nitrate khác nhau
}

\author{
Văn Nữ Thái Thiên ${ }^{1}$, Đặng Viết Hùng ${ }^{2, *}$, Nguyễn Thị Thanh Hoa ${ }^{3}$ \\ ${ }^{1}$ Viện Môi trường và Tài nguyên, ĐHQG-HCM \\ ${ }^{2}$ Trường Đại hoc Bách Khoa, ĐHQG-HCM \\ ${ }^{3}$ Trường Đại học Tài nguyên và Môi trường TP.HCM \\ *Tác giả liên hệ: dvhung70@gmail.com \\ Ngày nhận bản thảo: 23-7-2018; Ngày chấp nhận đăng: 11-10-2018; Ngày đăng: 31-12-2018
}

Tóm tắt-Các bể kỵ khí và thiếu khí được kết hợp với bể sinh học màng để tạo nên hệ thống AnaAno-MBR nhằm tăng cường khả năng xử lý thành phần hữu cơ và dinh dưỡng từ nước thải sản xuất bia. Mô hình Ana-Ano-MBR được làm bằng mica với dung tích 42 lít đã được vận hành với tải trọng hữu cơ $0,75 \mathrm{kgCOD} / \mathrm{m}^{3}$.ngày. Kết quả thu được cho thấy với tỷ lệ tuần hoàn nitrate là $100,200,300 \%$, hiệu quả xử lý $\mathrm{NH}_{4}{ }^{+}-\mathrm{N}$ và $\mathrm{TN}$ của mô hình là tương ứng với 95,1 và 76,$6 ; 98,5$ và 89,$6 ; 98,9$ và $90,2 \%$ và các giá trị đầu ra của $\mathrm{NH}_{4}{ }^{+}-\mathrm{N}$ và $\mathrm{TN}$ là nằm trong giới hạn của Quy chuẩn Việt Nam (QCVN 40:2011/BTNMT, cột $A)$. Hiệu quả xử lý COD và $T P$ là tương ứng với trên $90 \%$ và dưới $60 \%$. Hiệu quả loại bỏ phốt pho thấp là một nhược điểm của hệ thống Ana-Ano-MBR do các hạn chế về cấu trúc hệ thống và điều kiện vận hành. 